Fulong Wu, Jie Chen, Fenghua Pan, Nick Gallent, Fangzhu Zhang (2020) Assetization: the Chinese path to housing financialization. Annals of the Association of American Geographers (final accepted version)

\title{
Assetization: the Chinese path to housing financialization
}

Fulong Wu*, Jie Chen^, Fenghua Pan*, Nick Gallent*, Fangzhu Zhang*

*Bartlett School of Planning, University College London, 14 Upper Woburn Place, London, WC1H 0NN. (fulong.wu@ucl.ac.uk)

$\wedge$ School of International and Public Affairs, Shanghai Jiao Tong University, Huashan Road 1954, Shanghai 200030, China. (chenjie100@sjtu.edu.cn)

Acknowledgement: We would like to acknowledge the joint funding support on the project entitled "The financialization of urban development and associated financial risks in China" from UK Economic and Social Research Council (ESRC) (ES/P003435/1) and Natural Science Foundation of China (NSFC) (NSF71661137004). We also thank research assistance from Yi Feng. 


\section{Abstract}

Whilst the literature on the financialization of housing pays most attention to mortgaged and securitized homeownership and the penetration of capital into subsidized rental housing, forms of financialization are varied. In China, housing commodification and privatization has underpinned a growth in homeownership. One of the outcomes of financialization of housing is the transformation of owner-occupied housing into a financial asset for households' wealth. Despite a relatively low level of residential mortgage lending in China, both the absolute volume of mortgages and the proportion of GDP they represent are now rising. Housing value appreciation has driven a significant increase in the financing of housing consumption through multiple channels. This paper examines these channels and suggests that the financialization of housing in China is a critical part of the country's overall development model. It is further argued that the root of housing financialization in China is not mortgage securitization but the creation of owner-occupied housing as financialized asset to propel the wider financialization of the Chinese economy in the context of state-controlled financial environment.

Keywords: financialization, housing, homeownership, land finance, China 


\section{Introduction}

'Housing is for living, not for speculation'. In 2017, President Xi Jinping asserted a new principle for Chinese housing policy in his keynote speech to the $19^{\text {th }}$ National Congress ${ }^{1}$ of the CCP (Chinese Communist Party), reflecting on the way in which the exploitation of financial value might conflict with the other necessary functions of housing. Just as the built environment serves as a critical outlet for capital accumulation in western economies (Harvey 1978; 1982), property development also plays a central role in East Asia (Smart and Lee 2003; Haila 2015; Shatkin 2017). Housing commodification and land financialization have become major drivers of China's economic development (Tao et al. 2010; Hsing 2010; Lin 2014; Wu 2015a). The financialization of housing in China is a relatively recent phenomenon (Wu 2015a), but has played an important role in crisis management. The suspension of welfare housing provision in 1998 is widely regarded as a response to the 1997 Asian Financial Crisis (Logan, Fang, and Zhang 2010), as is the housing boom triggered by the injection of 4 trillion Yuan into infrastructure and urban development after the 2008 Global Financial Crisis (GFC) (Deng and Chen 2019). With regards to China, not enough attention has been given to the role played by owner-occupied housing (as asset) in the broader transformation of the country's regime of capital accumulation. China's recent effort to depart from dependence on the real estate sector, as a pillar of growth, suggests that research should now refocus on the meaning and function of housing financialization in China. Greater attention should be paid to individual consumption behaviours in housing, with a view to understanding how

\footnotetext{
${ }^{1}$ Full text of Xi Jinping's report at 19th CCP National Congress. Xinhua News. Available at: http://www.xinhuanet.com/english/special/19cpcnc/index.htm [Accessed November 3, 2017]
} 
homeownership is 'engineered' within the overall trend towards financialization, which serves as a critical link in the regime of capital accumulation.

Prevailing housing conditions in China provide the backdrop for this paper. Whilst house prices have been on an upward track, and prohibitively high compared to local household incomes (Chen, Hao, and Stephens 2010; Wu 2015a; Deng and Chen 2019), the country has achieved a high level of homeownership over the last two decades without a rapid acceleration in mortgage lending. Much international literature cites financialization achieved through the securitisation of mortgage debt as a key driver of increased domestic credit and housing demand, producing rising prices and reduced affordability through a 'housing-finance cycle' (Ryan-Collins 2019). But what has propelled house price inflation in Chinese cities given the relatively lower levels of mortgage lending? The mass privatization of public housing in the 1990s has been cited as a key factor underlying this phenomenon (Chen, Hao, and Stephens 2010; Wang et al. 2012). Privatisation also occurred during the post-socialist transition in Eastern Europe (Stephens, Lux, and Sunega 2015), resulting in a similar pattern of growth in homeownership without any commensurate expansion of mortgage indebtedness. In this paper we examine how China's own path to financialization -- and attendant transformation of the housing and land system -- has shaped the housing market.

Mortgages (direct bank loans) are a major capital source for home-purchase, besides households' own financial resources (savings). A proliferating literature on housing inequalities in China (Logan, Fang, and Zhang 2009; Wang et al. 2012; Huang and Li 2014) looks to land development and land finance for explanations (Tao et al. 2010; Lin 2014; Pan et al. 2017; Wu 2020) but seldom turns to the issue of financialization. This is a curious 
omission given that the link between housing and land -- in terms of financial dynamics -- is not at all clear.

This paper seeks to clarify the meaning of housing financialization in China. In doing so, it examines the financing of homeownership in China -- the sources of capital -- and assesses the implications of capital accumulation in China's overall development model. The paper is structured as follows. In the next section, following this introduction, we begin with a broad review of pertinent literature on the financialization of housing before looking at the relevance of key ideas to the Chinese situation. Then, in relation to the notion of the great 'wall of money' (Fernandez and Aalbers 2016) crashing into housing markets around the globe -- we explore the financial / capital sources of homeownership. In the fourth section, we examine the political economic conditions within which housing is 'assetized' as an investment vehicle. Fifth, the implications of financialized homeownership for China's development model are examined. And finally, we draw out the contribution of this paper to analysing the financialization of housing in China.

\section{The Financialization of Housing}

Theoretical perspectives

This paper engages with a number of important concepts. First, 'assetization' involves 'asset monetization' (Birch and Siemiatycki 2016) or, as Birch (2017) defines it, the transformation of otherwise illiquid property into a revenue-generating resource with recurring income 
streams -- hence 'capitalized property'. Those income streams may not, however, be constant. For example, a house can be purchased and rented out for a period of time and then left vacant. It remains an 'asset' as the initial capital investment can be recovered, with additional capital appreciation, at the end of the holding period. Therefore, one of the essential features of an asset is its potential to achieve future value appreciation, with use value preserved and consumed over an extended period. Its exchange value does not need to be 'cashed out' immediately for it to be assetized: rather, it is its potential to generate financial gain continually or episodically that makes it an asset. Assetization is the supply-side of financialization (Ward and Swyngedouw 2018: 1080) or how '[...] future income [is] capitalised in the present through credit' (ibid, 1091). In this paper, assetization is a process that shifts the balance between use and exchange value, increasing the potential (and desire) of extracting financial income from property: it is the process of making exchangeable commodities, or assigning exchange value, to things that were previously thought to have only use value.

In turn, the related concept of 'commodification' involves a re-prioritisation of exchange over use value: making goods tradeable but, with close reference to assetization, commodification is about the use of market means to achieve consumption while assetization stresses the expectation for asset value increase. In this paper, housing commodification is a primary stage of financialization: the transformation and treatment of housing as a commodity with exchange value rather than a welfare good, with only use value.

Thirdly, instead of viewing financialization as '[...] the increasing dominance of financial actors' (Aalbers 2016a) or 'as a trend towards a greater reliance on assets and/or debt' (Ward, van 
Loon, and Wijburg 2019), we understand financialization to be a process through which otherwise non-tradeable goods become, first, tradeable commodities and, subsequently, investment assets with high liquidity. Through a process of financialization, goods with enduring use value either become investable assets purchased by households (motivated to accumulate wealth) or by firms (seeking new income streams and enlarged market values). Financialization is a process that involves commodification, assetization and, ultimately, capitalization. Hence, financialization is not necessarily driven by 'penetration of capital' which denotes the expansion of finance capital into a new area (e.g. housing, infrastructure, farmland etc.) and, through the processes described above, a shift in the balance between use and exchange value with a view to creating new financial products. The penetration of capital into housing in China, still a relatively new phenomenon, depends on a number of unique institutional settings.

Fourth, 'regime of accumulation' is used in this paper to refer to those structures that enable different forms of capital and asset accumulation. A number of scholars view financialization as a special regime of accumulation. Krippner (2005: 174), for example, defines "financialization as a pattern of accumulation in which profit making occurs increasingly through financial channels rather than through trade and commodity production." Our view is that financialization is not merely profit-making through financial channels (e.g. the rising financial sector in the economy) but also creating and deploying financial instruments based on assets.

The extant literature on financialization covers three core strands: financialization as a regime of accumulation, financialization as the rise of shareholder value, and the financialization of 
everyday life (Christophers 2015; Aalbers 2016b). This pattern of accumulation involves “[...] the increasing dominance of financial actors, markets, practices, and measurements, and narratives, at various scales, resulting in a structural transformation of economies, firms (including financial institutions), state and households." (Aalbers 2016a: 3) Although much attention is being focused on the financialization of land and housing, forms of financialization (in different places) and outcomes remain under-researched and under-theorized (Aalbers and Christophers 2014; Aalbers 2017). Housing has become an important 'object' of financialization as it is exploitable through the operation of subprime mortgage markets (Aalbers 2008). Financial techniques and instruments -- from credit rating to securitisation -help convert that spatially-fixed object into an exchangeable and tradeable liquid financial product (Gotham 2009). Fernandez and Aalbers (2016) analyze the relationship between housing and financialization through the lens of varieties of capitalism. They contend that housing can be mobilized to absorb the 'wall of money' that is circulating in global financial markets and which is seeking investment opportunities. Housing mortgages are considered 'high-quality collateral' (Aalbers 2016b) and are therefore attractive to investors. This strand of research follows the theory of 'capital switching' in advanced capitalism (Harvey 1978; 1982).

Housing and the land it occupies has the potential to become a financial asset (Harvey 1982) and a place to park capital. Harvey's framework provides a key reference for interrogating the linkage between housing financialization and economic development, proposing that capital switches between complementary 'circuits' in response to cyclical over-accumulation in the primary (productive) circuit. Later scholars have found it difficult to verify those switches (see, for instance, Beauregard 1994) but have observed cyclical patterns of transaction activity 
through economic cycles. The relevance of his framework here is that we view the built environment as a financial asset, not because of any proliferation of mortgage securitisation against that asset, but because housing has been promoted as an investment vehicle for households, looking to increase wealth and support personal consumption, and for developers using the housing pre-sale system to finance development. Assetization, in our view, is a further development of Harvey's notion of mobilizing land as a financial asset. It has been suggested that "[...] the assetization of land is one of the key processes through which financialized neoliberal restructuring unfolds." (Ward and Swyngedouw 2018: 1093) Theurillat, Vera-Büchel, and Crevoisier (2016) describe the process through which capital valued in financial markets is transformed into real capital through urban development in China. They argue that the creation of financial assets has changed the logic of urban development, because in the 'financialized city' urban development is based on a logic of portfolio management, as investors compare the financial risks and yields of one real estate investment fund with another (ibid: 1512).

Part of the housing financialization literature analyses the financial technology that facilitates the credit scoring and risk-based pricing needed for the securitization of mortgage debt (Gotham 2009). However, the financialization of housing involves more than the securitization of mortgages, particularly when looking at different countries. While scholars have argued that housing finance has come to play a pivotal role in the modern macroeconomy (Schwartz and Seabrooke 2008; Jordà, Schularick, and Taylor 2016; Bohle 2018), institutional differences in housing finance systems between countries remain undertheorised (Blackwell and Kohl 2018). Boléat (1985: 7-8) places housing finance systems into four categories: personal lending, contractual lending, lending by specialist deposit-saving 
institutions, and lending with funds from issuing bonds. Another classification from Blackwell and Kohl (2018) makes the following modal distinctions: direct finance mode, deposit-based finance mode, bond-based mode and state finance mode. The literature also reveals that national housing finance systems differ in terms, firstly, of how the housing finance channel is integrated with the general financial market (Aalbers 2017) and, secondly, the liquidity of housing credit (Schwartz and Seabrooke 2008; Bohle 2018). Blackwell and Kohl (2018) attribute significant heterogeneity in housing finance systems across OECD countries to a combination of domestic capital market structures and historic path-dependence. Countries, for example, that have been historically bond-based have been slow to develop mortgage securitisation (ibid.). More broadly, they suggest that securitisation is an exception rather the norm in the broader and longer history of housing finance.

Many scholars have shone a light on the complexities and contradictions of financialization. Jordà, Schularick, and Taylor (2016), for example, show that real estate lending, as well as levels of household debt, differ significantly between advanced economies. Another important correlation exists between labour politics and house price inflation (Johnston and Regan 2017), whilst Bohle (2018) illustrates a core-periphery contrast in patterns of housing financialization across Europe, and Kohl (2018) shows that financialization is not universally linked to higher rates of homeownership. Further, analysis by Schwartz and Seabrooke (2009) reveals that even in the US, the securitisation of mortgage debt varies greatly over time and is sensitive to regulatory change. This body of work supports Aalbers' (2017:550) observation that "[...] the financialisation of housing is variegated, path-dependent and highly uneven" and underpinned by more than just debt securitisation. Our proposition, that assetization is core to the financialization of housing in China (where mortgage funds are raised almost 
entirely through deposit savings, including compulsory savings schemes such as a Housing Provident Fund [HPF], and mortgage securitisation is rare), fits with the view that the experience of different countries is institutionally and historically rooted and therefore variegated.

Viewing financialization as assetization means that ownership (property rights), and the expanding asset pool (of commodity housing), plays a critical role in future value creation as part of a bigger capital accumulation process. Crouch (2009) argues that in 'privatized Keynesianism' homeownership is the core household asset and further growth in homeownership is used to boost consumption. From the perspective of financialization, homeownership is itself treated as a financial asset (Forrest and Hirayama 2015). Whilst rates of homeownership have risen in many places, pathways to growth have been different. Stephens, Lux, and Sunega (2015) reveal that, in post-socialist economies, the retreat of the state from housing provision has not meant the rise of a fully-financialized housing market, but rather a legacy of debt-free homeownership (through the privatisation of public housing), inter-generational transfer and a tendency towards self-build. Governments in post-socialist countries adopted different responses to the 2008 GFC (Bohle 2014). While some turned to private market actors for respite from the crisis, other adopted 'far-reaching interventionist policies'. In the East Asian context, some government sought to expand homeownership by promoting "[...] the asset base of family centred welfare provision." (Ronald and Doling 2010: 233) The GFC triggered a range of national responses: some countries have rowed back from promoting property-based welfare, whilst others have continued to on this path. 
Our principal focus in this paper is the creation of homeownership for capital circulation and accumulation rather than the cross-over of the financial sector into housing and the consequent importance of financial capital in housing outcomes. Assets can both appreciate and depreciate in monetary value (Harvey 1982: 84). This is the essence of assetization, which aims to achieve asset value appreciation, often with the assistance of financial leverage. By engaging with Harvey's 'over-accumulation' thesis, expanded by Engelen et al (2011), it is possible to view the financialization of housing in China as part of an overall strategy to cope with over-accumulation in the Chinese economy. Over-accumulation was particularly evident during recent financial crises -- the 1997 Asian Financial Crisis and the 2008 GFC. In order to boost domestic consumption, it was decided that housing should become a key economic sector. This was actioned through a fiscal stimulus package that generated its own wall of money, similar to the one studied by Fernandez and Aalbers (2016).

Seen against the backdrop of rapid growth in the Chinese economy, assetization becomes a means of absorbing the extraordinary increase in money supply. There are obvious parallels with Harvey's assertion that the built environment acts as a consumption fund: an outlet, or pressure valve, for surplus capital -- which he labels capital's secondary circuit. But assetization encompasses more than the release of pressure: it also assists in the accumulation of capital to meet increased demand in the primary circuit. The long-term undersupply of housing in urban China before its commodification, combined with the state's long monopoly on land supply, made assetization a highly attractive proposition for homeowners and developers. Their pent-up appetite for wealth accumulation and extraction super-charged the expansion of housing supply in the post-reform period. 
Financial contexts of housing financialization in China

In addition to the puzzle of sustained soaring price and persistently low mortgage levels, a number of other unique features of the Chinese situation have already been identified by scholars working on housing in China. First, the pre-reform period was characterised by acute housing under-supply -- and therefore a backlog of unmet demand for decent housing that could be exploited after market liberalisation. This meant, second, that rapid urbanization in China since the 2000s was underpinned by a sudden unleashing of that demand. Third, it was therefore inevitable that the consumption of housing would feature prominently in China's spectacular economic growth. This very general context mixes with some more peculiar cultural drivers: for example, the role that housing plays in signalling social status in the 'marriage market' (Wei, Zhang, and Liu 2017). The gender imbalance arising from the onechild policy -- a greater number of males than females -- gives impetus to the pursuit of homeownership as a prerequisite of marriage, with young men and their families willing to pay a high price for a home. Moreover, the under-development of the financial system noted above has resulted in limited access to productive investment (Yang 2012) and therefore privileged housing as the main investment vehicle for ordinary households. The desire and need to invest in housing is also amplified by shortcomings in China's social security system: viewed by households as a form of asset-based welfare, homeownership provides a hedge against future financial risk (Yang, Fan, and Cheung 2017). There are of course similarities here with the experience of other countries in the west (Rossi 2017) and across south-east Asia (see Yuen 2002; Smart and Lee 2003; Doling and Ronald 2010). 
It was noted above that issues of financialization have not always featured in the literature on housing reform and commodity housing in China. Studies have often been preoccupied with tenue change and housing inequalities (Logan, Bian, and Bian 1999; Li and Yi 2007; Wang et al. 2012; Huang and Li 2014). A few have looked at housing finance and affordability (Li and Yi 2007; Chen, Hao, and Stephens 2010; Li 2010). In contrast, there is a burgeoning literature on China's land-driven urbanization (Hsing 2010; Tao et al. 2010; Lin 2014; Theurillat, VeraBüchel, and Crevoisier 2016). While it is recognised that investment in infrastructure -- built on the land finance model -- has resulted in sometimes alarming levels of local government debt (Tsui 2011; Pan et al. 2017), the link between housing consumption, real estate markets, and the financialization of land has received less attention. Mega projects and events (Zhao et al. 2017), place-promotion, place-branding and entrepreneurial city planning (Wu 2015b) and spill-over effects from industrial development to residential land (Tao et al. 2010) present possible lines of enquiry. For example, local governments use subsidized land and infrastructure to catalyze manufacturing investment, leading to agglomeration of population and generating demand for housing and commercial land, which is sold at a higher price (Tao et al. 2010). But how housing purchase is linked with development finance has not been examined in any detail.

While housing commodification and financialization are related, they refer to different aspects of housing development. Housing commodification in China often refers to the development of specific types of new housing that is sold and bought through the housing market. That housing is invariably built on land that has been purchased through the stateregulated land market. Housing commodification therefore references the market approach to housing production and consumption. 
Housing financialization, on the other hand, refers to the wider financial outcomes of housing commodification and is concerned with asset values, financial sources and financial implications. Through commodification, an asset value is created. The pool of assets thus absorbs capital (see earlier discussion of capital switching). Securitization of mortgages offers one means of transforming the built environment into 'liquid' financial assets to absorb capital (Gotham 2009) but is not prevelant in China. In the context of economic growth and restructuring in China, housing commodification may be a prelude to a wider financial process to absorb household savings, leverage development finance and trigger money creation. This is more appropriately referred to as financialization than commodification, and focused on housing tenure change.

Housing financialization in China primarily relates to homeownership because social housing was privatized during the reform period and social rental housing is under-developed. Recently, greater attention has been paid to financialization of the built environment and related capital inflow and switching. For example, suburban development has been interpreted as capital finding an investment outlet (Shen and Wu 2017). The role of property development industries in the production of urban space is likewise interpreted as financialized space production (Theurillat 2017).

Housing as an asset cannot be separated from land (see Ryan-Collins, Lloyd, and Macfarlane 2017). However, in China, land ownership and housing ownership are legally detached and this can give the impression that they are developed, and assetized, separately. Our view is that the assetization of housing must be understood as part of a broader mobilisation of land 
as a financial asset (Ward and Swyngedouw, 2018), as the basis of land development and the extraction of rent. However, China's broader financial context means that the aim of housing assetization is not to create collateral for the leverage of bank loans (hence the lower rate of mortgage lending, as a proportion of GDP, and the under-development of its secondary mortgage market and securitization), but rather to encourage households to convert savings into housing consumption and investment. And, in relation to land, limits on its assetization are illustrated by the work of Zhang (2018). He examined the land certificate system in Chongqing, which converts rural land development rights into tradeable market commodities, and gives one example of how local government in China as tried to mobilise rural land as a financial asset. Nevertheless, restricted by the dualistic land tenure system as well as the legal constraint of 70-year land use rights, the assetization of land in China is slow and clearly distinct from the assetization of the housing that sits on that land. Wu (2020) examines the role of land reserve center in land financialization and suggests that the state development corporation and other financial forms such as bonds are used.

The financial context of Chinese housing financialization has three core aspects. First, China has seen significant capital liquidity (shown as $\mathrm{M} 2$ ) through positive monetary policies. During the growth of foreign currency reserves and renminbi appreciation in the 2000s, the inflow of foreign investment contributed a significant source of capital formation. But foreign investment declined after 2008. This was compensated for by a fiscal stimulus package of 4 trillion Yuan (of which 2.3 trillion Yuan were mobilized by local government through its investment platforms) and provided a significant source of capital liquidity, providing the source of China's own 'wall of money'. Indeed, there has been a significant increase in 
monetary supply, measured by $M 2$, which reached 167.7 trillion Yuan and 2.4 times GDP in 2017 (Figure 1).

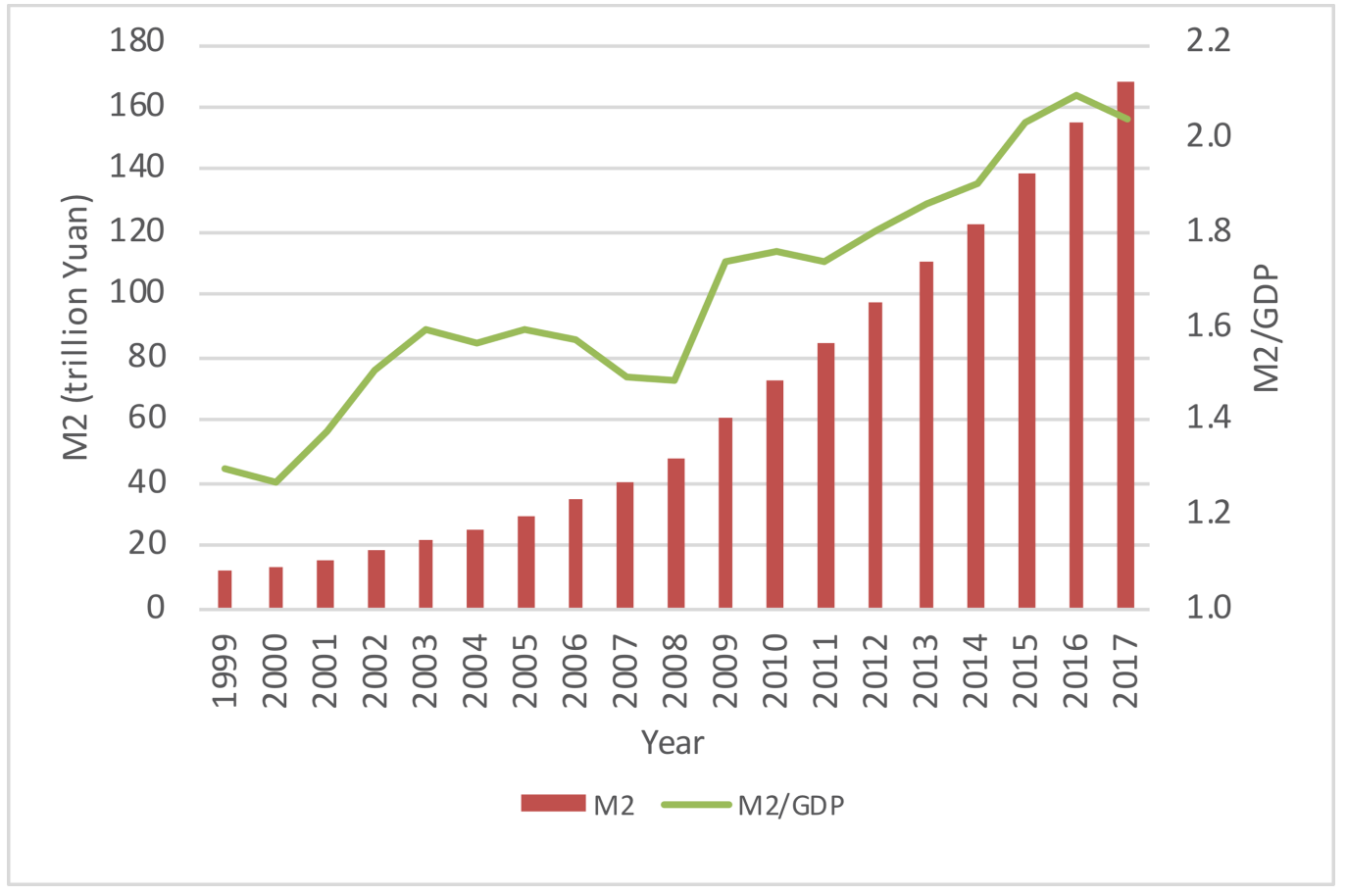

Figure 1 The change in monetary supply measured by M2 in China Source: People's Bank of China, China Statistical Yearbook

Second, China has also seen continuing high saving rates, with savings mostly deposited in state-owned banks. Double-digit economic growth, a high savings rate, rapid accumulation of household wealth, and rising disposable incomes has been accompanied by widening socioeconomic inequality. In 2017, Chinese GDP was 82.7 trillion Yuan, which is nearly 35 times greater than the figure for 1978, even after accounting for inflation. However, domestic household consumption has lagged behind and was only 32.3 trillion Yuan in 2017, accounting for less than 40 percent of GDP. It was above 50 percent in the 1980s. Low consumption and investment-driven growth have been hallmarks of the Chinese economy since the early 1990s (Yang, Zhang, and Zhou 2012). However, disposable income has grown steadily, accounting for 60 percent of GDP in 2017 (reaching 36.1 trillion Yuan and leaving a surplus, above 
consumption, of 3.8 trillion Yuan). That surplus is mainly converted into bank savings. China has traditionally been a nation with high savings rates. The savings rate as a percentage of GDP averaged 35 percent in the 1980s, growing to 41 percent in the 1990s and then to 50 percent in the early 2000s (Yang, Zhang, and Zhou 2012). In 2017, the total savings rate was 78.4 percent. Figure 2 shows the increasing trend in household savings (bank deposits) and its size relative to GDP over the period of 1997 to 2017. China's high savings rate has been seen both as a problem -- idle capital -- and as an opportunity to exploit through the assetzsation of housing and its links to land-finance.

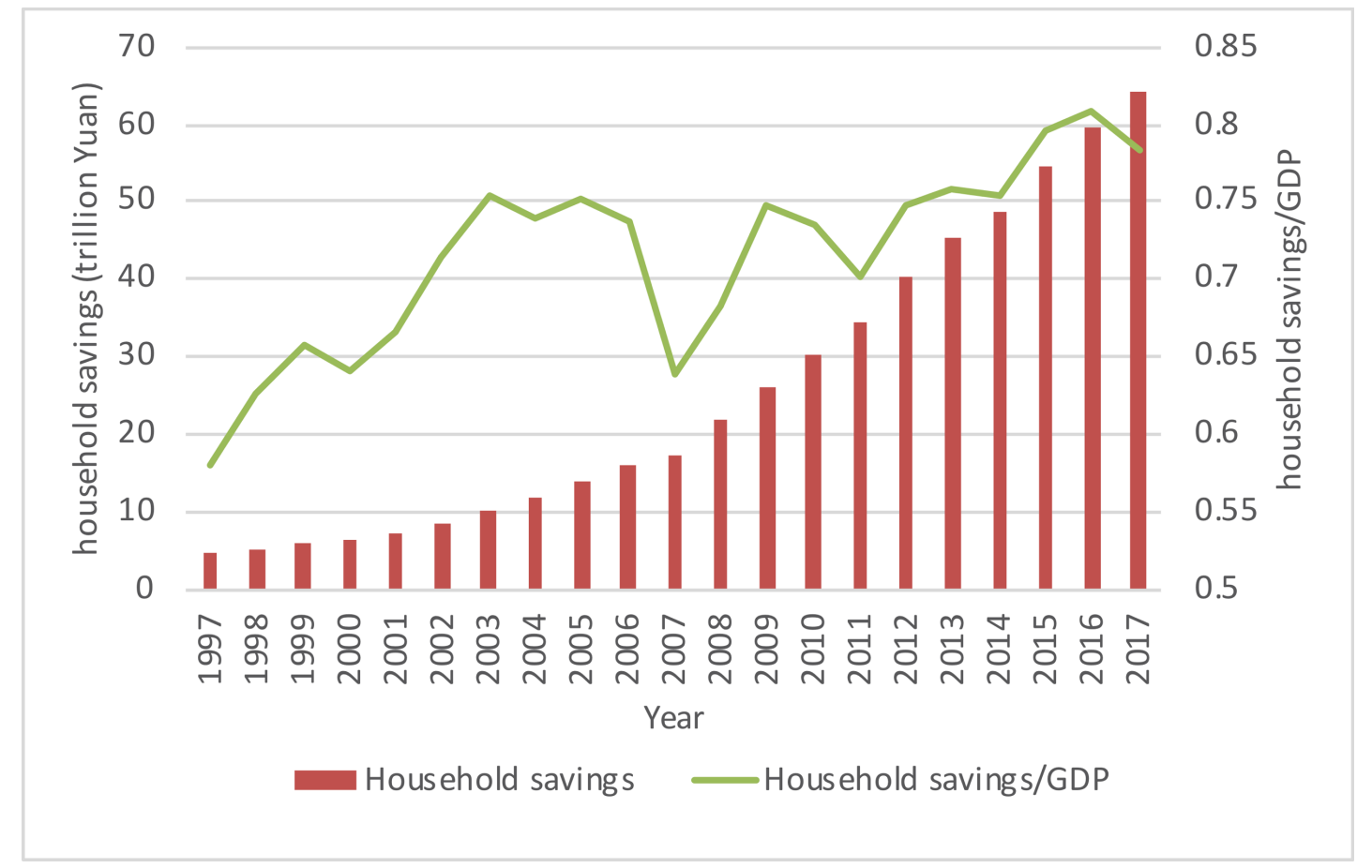

Figure 2 The household savings and its size relative to GDP in China (1997-2017) Source: China Statistical Yearbook

Third, debt finance is now playing a bigger role in driving housing consumption, although levels of household debt are widely regarded as manageable. According to Bank of International Settlements, total household debt as a share of GDP was 48 percent in 2017. 
The increase in household debt exceeded the increase in household savings for the first time in 2016. This may, ultimately, affect the loan-to-value (LTV) ratio of domestic mortgages, with significant increases in house prices -- particularly in the first-tier cities -- resulting in higher levels of household indebtedness. But levels of mortgage borrowing remain low compared to many advanced economies. Total household debt to GDP reached 53.2 percent in 2018 . The ratio of household debt to disposable income now exceeds 121 percent. Figure 3 shows the change in the household debt ratio.

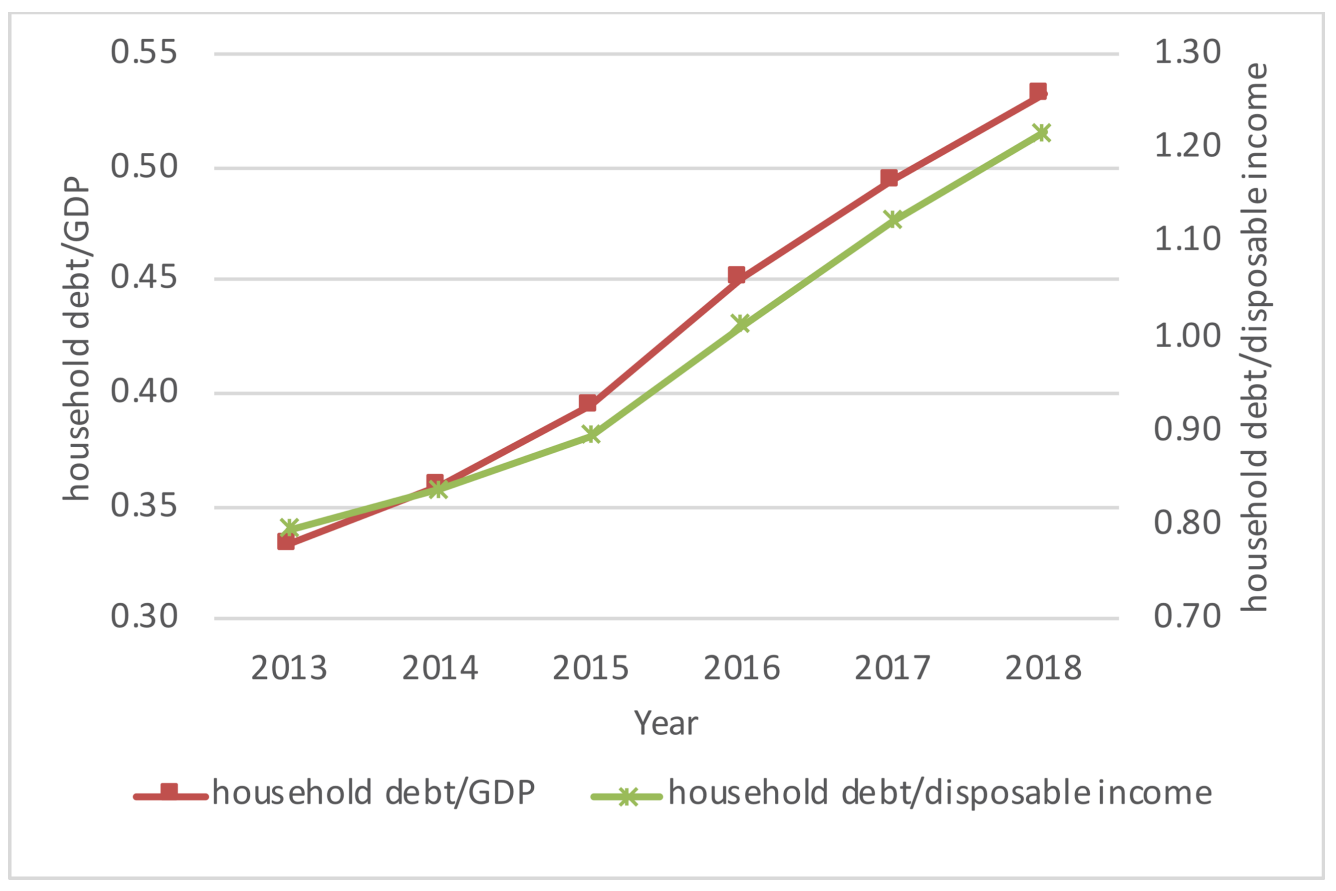

Figure 3 Increasing household debt measured by its share of GDP and the ratio of household debt to disposable income in China Source: People's Bank of China, China Statistical Yearbook

\section{Financializing homeownership: financial and capital sources}

Compared with advanced liberal market economies, China has a very high level of homeownership. This has been achieved through both the privatization of public housing and 
the development of commodity housing. According to a nationwide 1 percent population survey in 2015, 79.2 percent of Chinese households in urban areas owned their homes. 30.8 percent of these had accessed ownership via market purchase (of new-build or second-hand property); 34.1 percent had built their own homes; and 14.3 percent had benefited from the privatisation of public housing before 1998 or purchased subsidised affordable housing after that date. China has a remarkably low level of mortgage utilization relative to the total value of housing purchased. Patterns of income, savings and debt offer some clues to the way in which homeownership if financed but the intention now is to explore that issue in greater detail.

Historically, the privatization of public housing played a role in the growth of homeownership. Home purchase was heavily discounted and, coupled with rising disposable income, that privatisation eased the transition of many households into the commodity housing market (Logan, Fang, and Zhang 2010), many of which went on to purchase second and third homes. Although mortgages were sometimes used to access commodity housing, loans tended to be paid back quickly as disposable incomes grew. The limited use of mortgages has been illustrated in research by Li and Yi (2007). Surveys in Guangzhou in 2001 and 2005 revealed ' "[...] personal savings and parental contributions [to be] the most important sources of home finance." (ibid, 409) China's new membership of the World Trade Organization triggered a sustained boom after 2001, marked by rising house prices and increasing rates of ownership. But by 2005 , the average LTV ratio was 59 percent and "mortgage loans still contributed only 15.1 percent to the home purchase fund." (ibid, 419) Their findings reveal that even in an open and market-oriented city like Guangzhou, which was experiencing rapid growth in the mid-2000s, households continued to rely on their own financial resources for home purchase. 
Just 22.6 percent of purchases involved any mortgage loan finance, and even in those cases loans were repaid quickly. This prompted the conclusion that "high saving enables many households to purchase an apartment without having to seek financial loans." (ibid, 422)

In later work, comparing Guangzhou (2005) with Shanghai (2006-2007), Li (2010: 864) observed similar patterns of loan take-up. This time, the Guangzhou figure was 27.3 percent compared to 31.2 percent in Shanghai. Li went on to note a 'reluctance' amongst many homebuyers in China to 'resort to debt finance'. These snapshots confirm homebuyers' relative lack of engagement with mortgage finance in the 2000s. National figures are perhaps even more striking: domestic mortgage debt was equivalent to just 1.4 percent of GDP in 1999, rising to 17.2 percent in 2013 (Chen and Deng 2014). From this relatively low base, there has been an increase in real estate loans since 2013. By 2017, the total value had risen to 32.25 trillion Yuan, of which 21.86 trillion comprised domestic mortgages, in a relative size of 31.9 percent of GDP.

These figures put China in an odd position on the spectrum from 'developmentalist' to 'liberal' market models. Its mortgage-to-GDP ratio is higher than that of 'statist-developmentalists' (which average 28.2 percent) but its owner-occupation rate exceeds that of the liberal markets' (which average 70 percent) (Schwartz and Seabrooke 2009; Fernandez and Aalbers 2016). This means that China has taken its own path to owner-occupation, which has not been dominated by debt-financing. However, if transfers from the public stock are excluded from the owner-occupied sector, then the new owner-occupied sector (produced through the purchase of commodity housing) is just 45 percent: less than the 58 percent average for statist-developmentalist markets. China moved 45 percent of its households into owner- 
occupation with a mortgage-to-GDP ratio of 32 percent, making it more (debt) financialized

than other countries in this group.

Moreover, in the 'commodity housing' sector, the use of mortgages for home-purchase increased steadily from 2011, reaching a 2016 peak of 50 percent (Figure 4). That figure has since halved, to 25 percent, as a result of state control over mortgage borrowing in many larger cities. The policy of mortgage restriction (xian dai) ${ }^{2}$ shows that whilst China has experienced a process of housing financialization, transforming homeownership into an investable asset while the state exerts strict control over the pace of that financialization.

\footnotetext{
2 The nation-wide mortgage restriction policy was first enacted as a component in the China State Council's policy package to cool down the property market on January 10, 2010. All financial institutions were instructed to increase the minimum down-payment ratio of mortgages from 30 percent to 40 percent for applicants who had owned a home. This policy became stronger in the China State Council's new policy package to cool down the property market that was announced on September 29, 2010. After this date, the minimum down-payment ratio was further lifted from 40 percent to 50 percent and the mortgage interest rate was to be set at no less than 1.1 times the benchmark loan rate to applicants who had owned a home. Meanwhile, the State Council ordered all commercial banks to cease issuing mortgages to all applicants who had already borrowed two home mortgages, and to cease issuing mortgages to all non-local residents without at least one year's local employment or tax payment record, and to set the minimum down-payment ratio to no less than 30 percent for all borrowers. The mortgage restriction policy was much relaxed by the authorities on Oct. 1, 2014, enabling those who had paid back mortgages to be treated equally, with preferential policy as first-time home buyers. In the new round of property market regulation that swept across all major cities in the spring of 2017, there is now no nation-wide policy and municipal governments are given the discretion to design and enact their own cooling-down policy packages including mortgage restriction policies. However, most major cities have enacted very stringent mortgage restriction policies. For example, the minimum down-payment ratio of a mortgage is 35 percent for first-time home buyers, 50 percent for second-time home buyers if the home to be mortgaged is 'common' housing, and 70 percent if the home to be mortgaged is 'luxury' housing.
} 


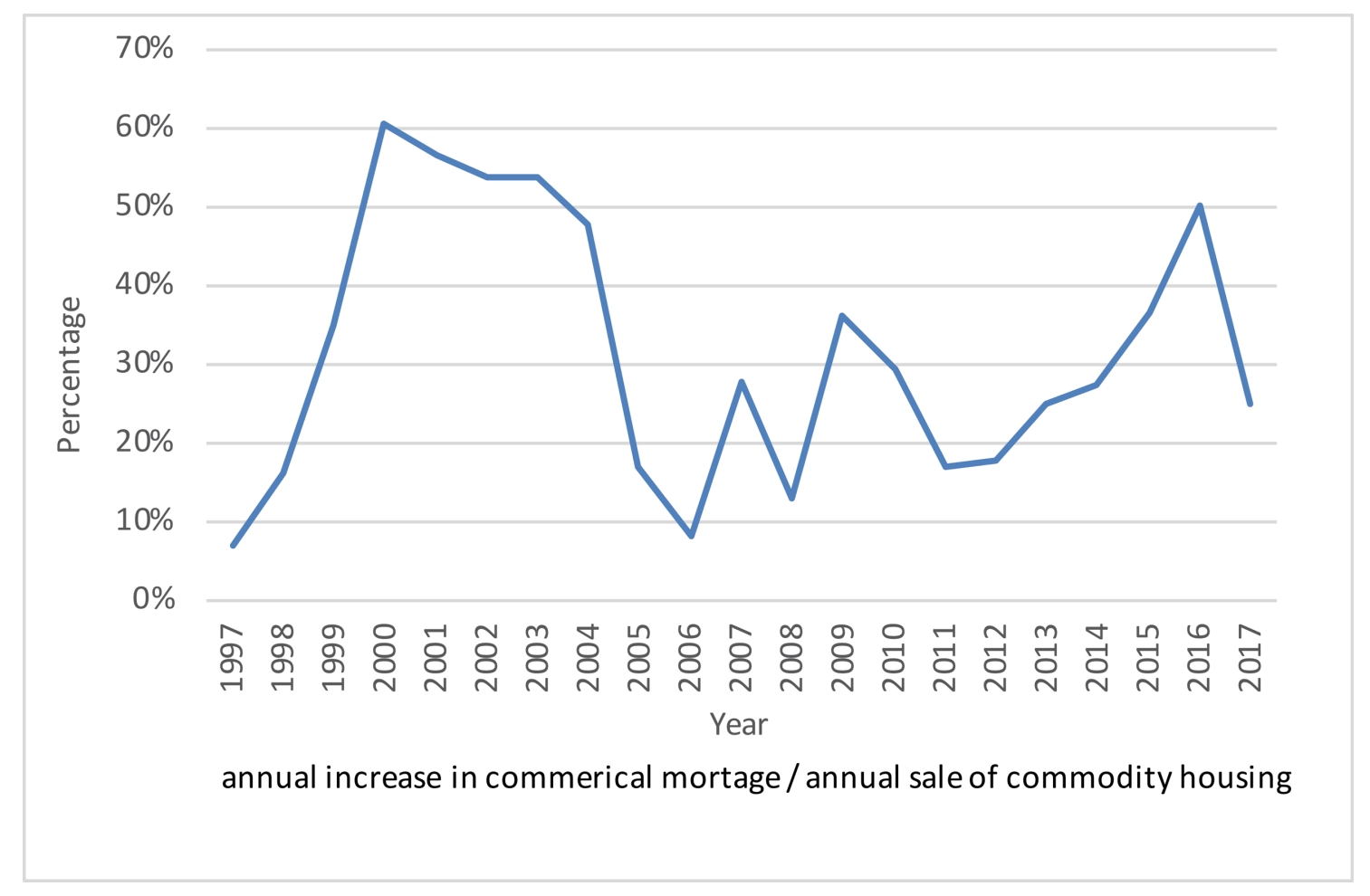

Figure 4 The contribution of commercial mortgage to in commodity housing purchase Source: People's Bank of China, China Statistical Yearbook

In addition to commercial mortgages, China has set up a compulsory saving scheme -- the Housing Provident Fund (HPF) -- to provide loan credit towards house purchase and related consumption expenditure, including rents and renovation (Chen and Deng 2014). The scheme requires all salaried employees to contribute between 7 percent and 10 percent of their salaries into a personal HPF account, while their employers provide matched contributions. The outstanding HPF loan balance was 1.68 trillion Yuan in 2012, growing to 4.50 trillion Yuan by 2017, according to Ministry of Housing, Urban and Rural Development (MOHURD). It accounted for about a fifth of total mortgages advances. HPF loans are not regulated by the People's Bank because the funding sources are outside the banking system, although it is included in the LTV limit of 70 percent (see below). HPF loans are an addition to bank 
mortgages for many homebuyers. They help others, otherwise constrained by more limited incomes or restrictions on mortgage access, to purchase homes.

China exerts tight control over household borrowing. In order to manage the financial risk arising from an overheating real estate market, the government limits the maximum LTV ratio to 70 percent as part of a general policy of mortgage restriction. A recent survey of six cities in China revealed LTV ratios of between 50 percent to 55 percent, suggesting a balanced mix of finance for housing consumption, comprising loans and family resources. However, recent rises in house prices mean that even if LTV ratios are low, the overall volume of borrowing is growing (and individual mortgages are getting bigger). The size of average mortgage payments increased from 10.4 percent to 25.6 percent of household income between 2010 and 2017 in the six surveyed cities. In one of the cities, 60 percent of households were spending more than 30 percent of their net incomes on mortgage repayments.

Besides commercial mortgages, Chinese households often borrow money for home purchase from parents and relatives. It was noted above that homeownership, or the capacity to enter into ownership, has become a prerequisite for marriage. Once a mother-in-law has sanctioned a marriage (the 'mother-in-law phenomenon'), the families of the bride and groom may contribute towards a deposit or mortgage payments. Cross-regional transfers are also common, as parents in small cities or rural areas sell their homes in order to help their children become homeowners. Likewise, urban renewal in third and fourth tier cities may generate cash from compensation, which again may be transferred to first-tier and larger cities to finance children's housing investments. 


\section{Assetization: housing as an investment vehicle}

How has housing financialization advanced under China's specific political economic conditions and in the context of a high savings rate, relatively low household indebtedness and rising disposable incomes? Despite the high savings rate, households have access to a very limited selection of investment vehicles. The stock market is small and volatile. The total market value of stock in Shanghai and Shenzhen by the end of 2017 was only 56 trillion Yuan, much smaller than the total market value of housing. In comparison, commercial mortgages totalled 21.86 trillion Yuan in the same year. But Chinese households aspire to better housing and the development of new, good quality 'commodity housing' has provided an outlet for that demand. But whilst 'new build' has been a major driving force for the housing market, a strong market for second-hand housing is now emerging. The nationwide survey of 1 percent of the population in 2015 revealed that roughly a quarter of (7.29 percent of 30.75 percent) households entering the commodity housing market did so by purchasing second-hand property. There is an increasing volume of trading in this market segment, resulting in a bidding up of prices as investors move money out of banks and into housing.

Between 2003 and 2013, the average real deposit rate in Chinese banks was 0.01 percent, whilst house prices rose by 15.7 percent (in first tier cities), 13.4 percent (second tier) and 11 percent (third tier) (Fang et al, 2016). Annual growth in the Shanghai Stock Market averaged 7.3 percent in the same period, but with high levels of volatility after the $2008 \mathrm{GFC}$. Because housing assets offer such good returns, home buyers stretch financially to access ownership. Although investments may not be entirely speculative, home-purchase is motivated (almost invariably) by a mix of use value and perceived exchange / economic value, especially as long- 
term investments to cover future household security and deliver 'asset-based welfare' (Doling and Ronald 2010). The result is that the commercial mortgage balance to household disposable income increased from near-invisibility in 1998 to over 74 percent in 2017 (Figure 5).

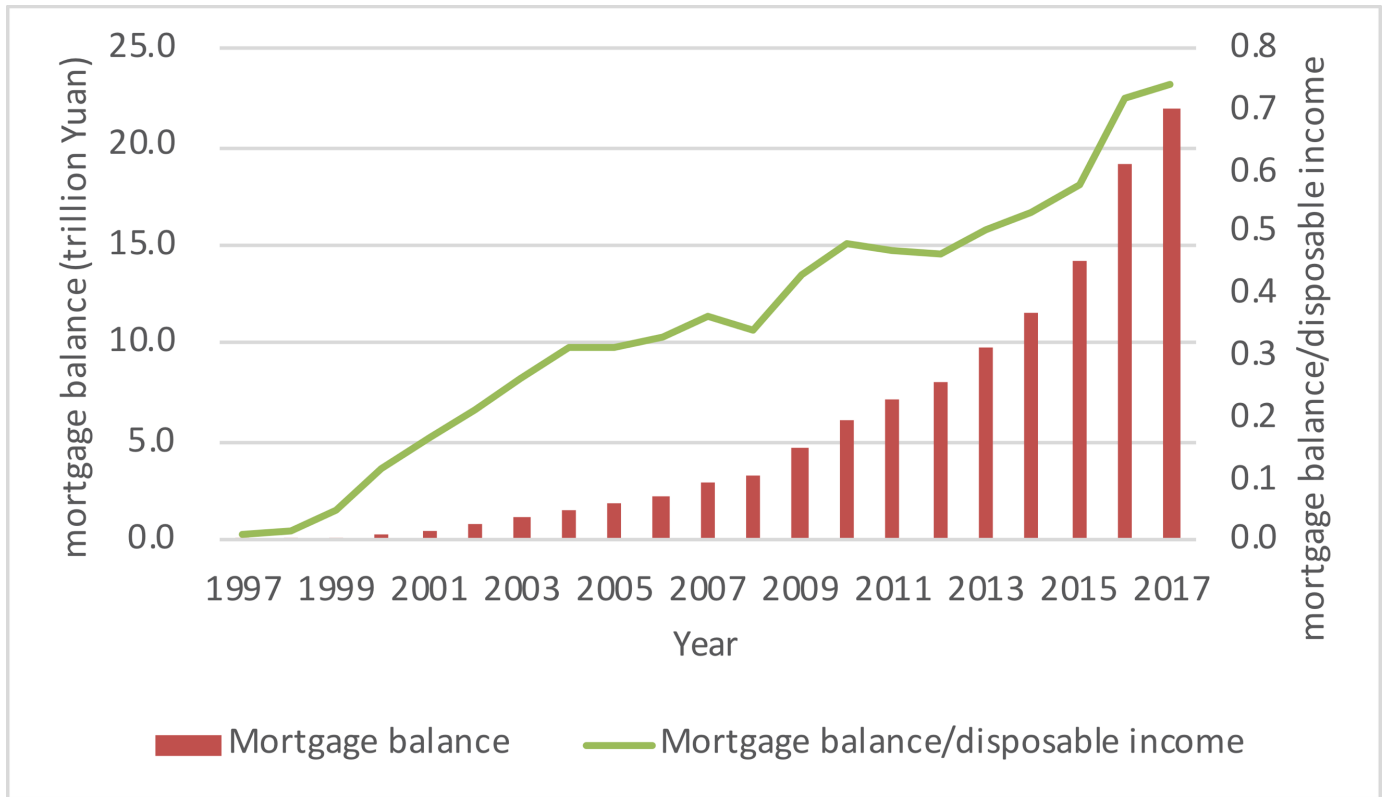

Figure 5 The ratio of mortgage balance to disposable income of urban residents in China Source: People's Bank of China, China Statistical Yearbook

The housing market is therefore an important engine of value creation, fuelled by the expectation of future price growth, underpinned by several contextual drivers.

First, due to the policy of agricultural land protection, the overall supply of land for housing is heavily constrained. Government has set a clear red-line: 18 trillion mu ( $1 \mathrm{mu}=15$ hectares) of agricultural land will be excluded from all future development. Moreover, conversion of land to urban use is fixed in annual quotas and only the state can acquire land from farmers. Second, urbanization has resulted in the concentration of population in major cities, 
especially the first-tier cities of Beijing, Shanghai, Shenzhen and Guangzhou. This has focused housing pressure and generated a sustained demand for affordable homes. Third, the shortage of housing in the pre-reform period, and lack of quality housing in particular, produced a gap between available supply and growing demand. This gap was further widened by the cessation of public housing programmes and slow progress towards replacement affordable housing provision. Fourth, estates with concentrations of affordable housing do not meet the aspirations of a growing middle class; their clear preference has been for new commodity housing, often located in master-planned estate and away from the old public housing stock. Overall, the combination of limited land supply and strong demand for new types of housing resulted in a sustained housing boom and rising prices, again fuelling value creation through the housing market. It has been characterized by the diversion of traditional bank savings into housing assets, which was given further impetus by the state's control of interest rates -- in support of an expansionist monetary policy -- in the years after the GFC.

Increased investment in housing became almost inevitable by the late 2000 s, given the limited selection of alternative investment products and the greater risks associated with wealth management products. That investment resulted in 20.5 million square metres of new housing being added to China's housing stock between 2008 and 2016. In 2017, the total value of new housing sales was 11 trillion Yuan, equivalent to 13.4 percent of GDP.

It was the under-development of China's financial market, and a lack of financial products, that propelled the assetization of housing during this period. This, combined with tight control over monetary policy (including saving and hence borrowing rates), sent a wall of money crashing into a housing market heavily constrained by strict limits on land supply. For the state, 
the capacity to control both monetary policy and land supply means that land and housing provide a steady anchor for the economy. This is in essence a 'spatial fix' as discussed by Harvey (1982), as the development of new housing sector allowed the Chinese state to adopt a more proactive monetary policy to stimulate the economy. The spatial fix is exemplified in new 'commodity housing', suburbanisation, and new towns in China (Shen and Wu, 2017). The rate of homeownership remains high as low rental yields mean that commodity housing is unlikely to be converted to private renting. There is no evidence that China is turning to financialized private landlordism and therefore no weakening of the social logic of private ownership. Elsewhere in the market, affordable rental housing is generally found in the informal sector and cannot be sold with legal title (Wu, Zhang, and Webster 2013). Informality replaces some of the safety net lost through the privatization of public housing. But its function is different. Informal housing rented in the urban villages provides income supplement, whereas tradeable formal housing (with legal title) in the cities is held for value appreciation.

These trends look set to continue into the foreseeable future: homeownership is associated with numerous social advantages, including access to better schools. Although China has recently extended rights of social service access (including education) in many cities to renters -- diminishing the relative advantage (use value) of homeownership -- long-term financial gains remain a key draw of ownership, prompting the purchase of homes that are sometimes left long-term empty and held merely for capital appreciation. Local media reports whole developments devoid of residents long after completion. The growth in ownership and house prices is also likely to be sustained by changing attitudes towards borrowing and debt finance. Homebuyers aggressively pursue opportunities, taking on ever-greater financial burden in 
order to access ownership. There are now some indications (reflected in the growing volume of mortgage advances) that the balance between family resource and debt finance in the housing market is shifting in favour of the latter.

China's is an expansionist economy in which households are willing to invest heavily in housing in order to share in the country's growth. But enthusiasm to buy and intense competition generates financial risk. Fang et al. (2016: 151) argue that "[...] housing prices are indeed expensive relative to the income[s] of many households, in particular, of the lowincome mortgage borrowers. While one can justify their willingness, despite the severe financial burdens, to buy homes based on expectations of persistently high income growth, the high price-to-income ratios observed across Chinese cities expose the housing market to substantial risks when households' expectations are subdued in the future, especially in the event of a sudden stop in the Chinese economy."

\section{Housing financialiation as an integral part of China's development model}

The Chinese economy has historically been driven by exports and investment, with relatively low rates of domestic consumption. The financialization of housing constitutes an important pillar of domestic consumption whilst stimulating investment in infrastructure, making land value capture possible in China's urban development model. Housing financialization, of the type described above, has become an important driver of domestic consumption (and therefore wider growth) in an otherwise state-controlled financial environment (for example, interest and exchange rates are fixed not by an autonomous central bank and / or money markets but by government for a mix of economic and political reasons. State control limits 
the influence of the market on rates and also inhibits the penetration of private finance into different sectors of the economy). The financialization of housing also plays a critical role in China's overall land-finance development model (see also Wu 2020), for two critical reasons.

First, presale receipts -- down-payments or deposits -- have become an important source of funding for housing development, with developers using these early receipts to substitute for bank loans, which have become increasingly difficult to access as government seeks to calm real estate speculation. In 2017, bank loans to developers totalled 8.32 trillion Yuan -- just 13 percent of total development finance. Presale (or pre-completion) deposits for homes bought 'off plan' exceeded that total, at 15 percent, whilst mortgages accounted for another 31 percent. Overall, funds from homebuyers provided 46 percent of all development finance. Given this reliance on finance originating from consumers, many big developers undertake accelerated projects, delivering rapid sale completions and limiting the use of bank loans or other financial instruments.

This means that, secondly, the housing boom is critically important to China's development model, which relies on monetary and investment expansion. It contributes to the expectation of future return, thereby sustaining capital flow into the built environment in the form of land finance for urban development. Rising prices drive capital mobility and financial mobilization and also make it easier for developers to raise finance, using land as collateral. Those same rising prices also generate an intensified demand for capital, and therefore underpin the increase in monetary supply, as shown in M2. A recent slowing of the housing market caused a sudden loss of interest in 800 plots of development land across China during the first seven 
months of $2018^{3}$, underlining the importance of a booming housing market to both the pace of development and local government's land revenues and tax income.

The financialization of housing plays a key role in China's overall accumulation model -- a reality demonstrated when the country was confronted with increased financial risks in 2015, arising from a slowing of housing sales. A policy of reducing the volume of unsold new housing (labelled 'housing destocking' or qu ku chun) ${ }^{4}$, particularly in third- and fourth-tier cities, was implemented through large-scale urban renewal and housing demolition followed by compensation to developers. Compensation was calculated against inflated housing values and therefore significantly boosted demand for new (unsold) housing in these cities. This move to deleverage transferred local government and developers' debt into household debt. The goal, in essence, was to leverage households' financial capacities to deleverage an overall economic debt ratio. Housing financialization thus played an important role in deleveraging. In the case of housing destocking in third- and fourth-tier cities, this also had the effect of converting old housing into an exchangeable asset, a process that contributed to the increase in monetary supply.

Housing financialization draws households into China's development model, mobilizing their agency and financial capacities. It converts private money into development finance,

\footnotetext{
${ }^{3}$ The SOHU news (2018-08-27), https://www.sohu.com/a/250296354_100231706

${ }^{4}$ According to NBSC, the total unsold inventory of commodity property hit a historical high of 739 million $\mathrm{m}^{2}$ (including 466 million $\mathrm{m}^{2}$ of residential housing) in January 2016. Meanwhile, property under construction at the end of 2015 comprised 7.36 billion $\mathrm{m}^{2}$, also a record high. As the annual volume of sales in China was around 1.0-1.2 billion $\mathrm{m}^{2}$ during 2014-2015, this implies that the market would take roughly 6-7 years to absorb this excess inventory. Thus, this over-supply emerged as a key economic issue towards the end of 2015. At the central economic working conference in December 2015, the destocking of real estate was included among government's five major tasks for 2016. A series of policies to stimulate the real estate market and promote the destocking of real estate were then enacted, such as reducing the down payment proportion of housing loans and reducing housing transaction taxes and fees.
} 
compensating for some of the deficiencies of China's stock market. The future value of ownership is the driving force behind this process, with private money -- deposit savings -underpinning the bidding up of land and house prices. Consumers and not banks or institutional investors are the engines of China's economic growth. Post-war homeownership was developed as a social project (Forrest and Hirayama 2015), associated with a mix of tenure-based economic and social advantages. In contrast, the current period of housing financialization is about the way in which asset value underpins economic growth. The drive towards homeownership is therefore a drive towards assetization -- motivated by the desire to share in that growth. We thus distinguish assetization from speculation, as the former delivers both current and future use and future investment value. This refunctioning of housing, as asset for the individual and a platform for growth is not without risk: it assumes that China will continue to see rapid economic growth and housing costs will align with rising household wealth. There is no guarantee that the historic combination of low household debt, high savings levels, and a booming housing market will continue forever.

\section{China's path to financialization - conclusions}

Built upon the aspiration for better housing, highly restricted land supply and a statecontrolled financial environment, the commodification of housing in China has mobilized households to invest in housing assets for value appreciation. Potential returns from housing far exceed those arising from bank deposits. The shift into ownership has resulting in rising household debt, albeit from a low starting base. Bank lending is not underpinned, as it is in some advanced economies, by debt securitisation. Rather, China's experience of housing financialization can more accurately be described as a process of assetization, which departs 
from standard models in two important ways. First, China's own 'wall of money' (Aalbers 2016b; Fernandez and Aalbers 2016) does not originate in the global financial markets but is rather rooted in high savings rates, historic under-consumption and investment-driven growth. Second, whilst the extant literature dealing with financialization draws attention to the penetration of financial capital into housing through processes including debt securitisation -- thereby privileging financial actors and practices -- China's own brand of financialization is characterized by the state capacity to provide monetary supply based on housing and land assets and the participation of millions of homeowners and mortgage borrowers. These, rather than financial actors, are the key agents of financialization in the Chinese case.

What then are the distinctive features of China's path towards the financialization of housing? In this paper, we have drawn attention to important differences between China and liberal capitalist market models: specifically, its relatively low level of reliance on mortgage lending to drive its housing market and hence lack of engagement with these instruments, including debt securitisation, that have been important elsewhere in increasing monetary supply and de-risking bank lending. This led us to describe China's economy as the one less centred on financial sectors, with a lack of circulating finanial capital and actors seemingly at odds with its high level of owner-occupation. Rising owner-occupation, however, can be attributed to the mass privitisation of public stock and, more significantly, the willingness of Chinese households to endure high levels of indebtedness and financial burden in order to gain future asset appreciation. 
It is notable that other post-socialist economies have achieved similar levels of homeownership, often as a result of the offloading of public housing to private households. The aim, frequently observed in post-socialist transition economies in Eastern Europe, was to reduce public responsibility for maintaining and managing a deteriorating housing stock whilst shifting to a model of asset based welfare, popular in some western thinking, particularly in the US and UK (Rossi 2017; see also Stephens, Lux, and Sunega 2015, for wider comparisons). The Chinese experience was, however, different in that it was built on the back of rapid economic growth in the post-reform period. There was an element of public housing privatization but this was secondary to the process of creating an outlet for surplus capital through the privatized development of new 'commodity housing' for sale -- the commodification process detailed in this paper.

These new housing assets were more than the products of financialization (Aalbers 2016b): they also played a vital role in credit creation. They are assets through which financialization occurs. In the study of post-socialist financialization, Büdenbender and Aalbers (2019) emphasizes the semi-peripheral position of their case -- Poland in the global economy. They propose a concept of 'subordinate financialization', suggesting "a key function of subordinate financialization is to absorb globally mobile capital -- the product of financialization in the

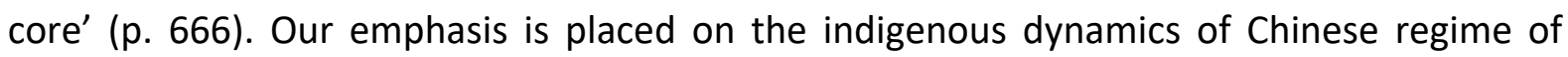
accumulation and related governance approaches of 'state entrepreneurialism' (Wu 2018). For this, we need to understand the 'China development model'.

The defining characteristic of the China development model are the clear linkages between the triad of (1) housing assetization, (2) the land-finance model, and (3) a broader shift in the 
Chinese economy towards making money and capturing value not through the production of goods and delivery of (non-financial) services, but through holding housing assets. China has taken its own path towards a form of financialization that now has a firm grip on most, if not all, modern economies (Krippner 2005; Aalbers 2016a). The contribution of this paper has been to show how housing is not merely an object to be financialized (through various instruments and technologies -- that deliver complex structured finance): rather, it occupies centre stage in the recent story of China's economic transition.

As a variegated form of housing financialization, China's large-scale promotion and delivery of homeownership as a financial asset brings a new dimension to the financialization literature. Assetization has been a core mechanism of profit-taking in the bio-economy through the treatment of bio-knowledge as an asset (Birch 2017), or in urban and regional regeneration through land-banking and asset acquisition (Ward and Swyngedouw 2018). This process of assetization co-exists with the penetration of financial capital (Fernandez and Aalbers 2016), the imposition of bondholders' value and financial gatekeepers (Peck and Whiteside 2016; Halbert and Attuyer 2016). Ward, van Loon, and Wijburg (2019: 124) argue that "assetization is a principal component of financialization and an important material mechanism driving neo-liberalisation." They focus on asset owners to finance their projects through capital mobilization. Here, the creation of housing assets allows the state to inject liquidity for urban development, on the basis that millions asset owners are willing to convert their savings into the capital to allow financial leverages deployed by the development sector. 
The Chinese case presented in this paper reveals financialization to be a trend towards greater reliance on assets for the creation of liquidity. Housing assets in China are more than 'the bearers of financialisation' (Aalbers 2016b): rather, they are instrumental in credit creation. In a bank-based financial system, assetization provides an anchor for the conversion of savings into assets for future economic returns, stimulating the growth of the mortgage market, and linking the exchange value of land with actual material use. Housing financialization materializes the bid land price. Value added during land-value capture is transferred into house prices, evidencing value appreciation. This, in turn, justifies the investment in housing as an asset with financial returns. This feedback loop between housing financialization and the land-finance model not only delivers development finance through the housing presale system but also increases the value of land collateral against which additional finance can be raised (Wu 2020), thereby increasing capital liquidity. Housing financialization plays a key role in the overall financialization of the Chinese economy, which is underpinned by the agency of domestic consumers rather than the power of financial actors and global finance. China operates a unique form of residential capitalism which conforms to neither the 'statist developmentalist' nor the 'liberal market' models (Schwartz and Seabrooke 2009; Fernandez and Aalbers 2016). Its hallmark is assetization through a mobilization of domestic consumption and a redirection of that consumption towards housing -- now arguably a key vehicle of China's continuing economic growth. Echoing the 'spatial fix' developed by Harvey (1982), China's housing assetization is closely associated with its over-accumulation in industrial production after the GFC; as a concrete form of financialization, its operation is not only achieved through shifting surplus capital but also engineered by the state's capital creation based on housing assets -- a state strategy (Wu, 2018), motivating millions enthusiastic homebuyers. 


\section{References}

Aalbers, M. B. 2008. The financialization of home and the mortgage market crisis.

Competition and Change 12 (2):148-166.

-- - 2016a. Corporate financialization. International Encyclopedia of Geography: People, the Earth, Environment and Technology: People, the Earth, Environment and Technology:1-11.

- - . 2016b. The financialization of housing: A political economy approach: Routledge.

- - . 2017. The variegated financialization of housing. International Journal of Urban and Regional Research 41 (4):542-554.

Aalbers, M. B., and B. Christophers. 2014. Centring housing in political economy. Housing, Theory and Society 31 (4):373-394.

Beauregard, R.A. 1994. Capital Switching and the Built Environment: United States, 197089. Environment and Planning A: Economy and Space 26(5): 715-32.

Birch, K. 2017. Rethinking value in the bio-economy: Finance, assetization, and the management of value. Science, Technology, \& Human Values 42 (3):460-490.

Birch, K. and M. Siemiatycki. 2016. Neoliberalism and the geographies of marketization. Progress in Human Geography, 40(2), pp. 177-198.

Blackwell, T. and S. Kohl. 2018. The origins of national housing finance systems: a comparative investigation into historical variations in mortgage finance regimes, Review of International Political Economy 25(1): 49-74.

Bohle, D. 2018. Mortgaging Europe's periphery. Studies in Comparative International Development, 53(2), 196-217. 
Bohle, D. 2014. Post-socialist housing meets transnational finance: Foreign banks, mortgage lending, and the pr.ivatization of welfare in Hungary and Estonia, Review of International Political Economy 21(4): 913-948.

Boleat, M. 1985. National housing finance systems: a comparative study. London: Croom Helm.

Büdenbender, M. and M. B. Aalbers, 2019 How subordinate financialization shapes urban development: the rise and fall of Warsaw's Sluzewiec business district. International Journal of Urban and Regional Research 43: 666-684.

Chen, J., and L. Deng. 2014. Financing affordable housing through compulsory saving: The two-decade experience of housing provident fund in China. Housing Studies 29 (7):937-958.

Chen, J., Q. Hao, and M. Stephens. 2010. Assessing housing affordability in post-reform China: a case study of Shanghai. Housing Studies 25 (6):877-901.

Christophers, B. 2015. The limits to financialization. Dialogues in human geography 5 (2):183-200.

Crouch, C. 2009. Privatised Keynesianism: An unacknowledged policy regime. The British Journal of Politics and International Relations 11 (3):382-399.

Deng, L., and J. Chen. 2019. Market development, state intervention, and the dynamics of new housing investment in China. Journal of Urban Affairs 41(2):223-247.

Doling, J., and R. Ronald. 2010. Home ownership and asset-based welfare. Journal of Housing and the Built Environment 25 (2):165-173.

Engelen, E., Ertürk, I., Froud, J., Johal, S., Leaver, A., Moran, M., . . Williams, K. (2011). After the great complacence: financial crisis and the politics of reform. New York: Oxford University Press. 
Fang, H., Q. Gu, W. Xiong, and L.-A. Zhou. 2016. Demystifying the Chinese housing boom. NBER macroeconomics annual 30 (1):105-166.

Fernandez, R., and M. B. Aalbers. 2016. Financialization and housing: Between globalization and varieties of capitalism. Competition \& Change 20 (2):71-88.

Forrest, R., and Y. Hirayama. 2015. The financialisation of the social project: Embedded liberalism, neoliberalism and home ownership. Urban Studies 52 (2):233-244.

Gotham, K. F. 2009. Creating liquidity out of spatial fixity: the secondary circuit of capital and the subprime mortgage crisis. International Journal of Urban and Regional Research 33 (2):355-371.

Haila, A. 2015. Urban land rent: Singapore as a property state. Oxford: Wiley-Blackwell.

Halbert, L., and K. Attuyer. 2016. Introduction: the financialisation of urban production: conditions, mediations and transformations. Urban Studies 53 (7):1347-1361.

Harvey, D. 1978. The urban process under capitalism. International Journal of Urban and Regional Research 2:101-131.

- - . 1982. The Limits to Capital. Oxford: Blackwell.

Hsing, Y.-t. 2010. The great urban transformation: Politics of land and property in China. Oxford: Oxford University Press.

Huang, Y., and S.-m. Li eds. 2014. Housing inequality in Chinese cities. London: Routledge. Jordà, O., Schularick, M., \& Taylor, A. M. (2016). The great mortgaging: housing finance, crises and business cycles. Economic Policy 31(85), 107-152

Johnston, A., \& Regan, A. (2017). Global finance, labor politics, and the political economy of housing prices. Politics \& Society, 45(3), 327-358.

Krippner, G. R. 2005. The financialization of the American economy. Socio-economic review $3(2): 173-208$. 
Li, S.-M. 2010. Mortgage loan as a means of home finance in urban China: A comparative study of Guangzhou and Shanghai. Housing Studies 25 (6):857-876.

Li, S.-M., and Z. Yi. 2007. Financing home purchase in China, with special reference to Guangzhou. Housing Studies 22 (3):409-425.

Lin, G. C. S. 2014. China's landed urbanization: neoliberalizing politics, land commodification, and municipal finance in the growth of metropolises. Environment and Planning A 46:1814-1835.

Logan, J. R., Y. J. Bian, and F. Q. Bian. 1999. Housing inequality in urban China in the 1990s. International Journal of Urban and Regional Research 23 (1):7-25.

Logan, J. R., Y. Fang, and Z. Zhang. 2009. Access to housing in urban China. International Journal of Urban and Regional Research 33 (4):914-935.

- - . 2010. The Winners in China's Urban Housing Reform. Housing Studies 25 (1):101117.

Pan, F., F. Zhang, S. Zhu, and D. Wójcik. 2017. Developing by borrowing? Inter-jurisdictional competition, land finance and local debt accumulation in China. Urban Studies 54 (4):897-916.

Peck, J., and H. Whiteside. 2016. Financializing Detroit. Economic Geography 92 (3):235-268.

Ronald, R., J. Doling. 2010. Shifting East Asian approaches to home ownership and the housing welfare pillar, International Journal of Housing Policy 10(3): 233-254.

Rossi, U. 2017 Cities in Global Capitalism, Polity Press: Cambridge.

Ryan-Collins, J., Lloyd, T. and Macfarlane, L. 2017. Rethinking the Economics of Land and Housing. Zed Books: London.

Ryan-Collins, J. 2019 Breaking the housing-finance cycle: Macroeconomic policy reforms for more affordable homes, Environment and Planning A 0(0): 1-23. 
Schwartz, H.M., and L. Seabrooke. 2008. Varieties of residential capitalism in the international political economy: old welfare states and the new politics of housing. Comparative European Politics 6 (3): 237-61.

Schwartz, H. M., and L. Seabrooke eds. 2009. The politics of housing booms and busts. Basingstoke, UK: Palgrave Macmillan.

Shatkin, G. 2017. Cities for profit: the real estate turn in Asia's urban politics: Cornell University Press.

Shen, J., and F. Wu. 2017. The suburb as a space of capital accumulation: The development of new towns in Shanghai, China. Antipode 49 (3):761-780.

Smart, A., and J. Lee. 2003. Financialization and the role of real estate in Hong Kong's regime of accumulation. Economic Geography 79 (2):153-171.

Stephens, M., M. Lux, P. Sunega. 2015. Post-socialist housing systems in Europe: housing welfare regimes by default? Housing Studies 30 (8): 1210-1234.

Tao, R., F. B. Su, M. X. Liu, and G. Z. Cao. 2010. Land leasing and local public finance in China's regional development: Evidence from prefecture-level cities. Urban Studies 47 (10):2217-2236.

Theurillat, T. 2017. The role of money in China's urban production: the local property industry in Qujing, a fourth-tier city. Urban Geography 38 (6):834-860.

Theurillat, T., J. H. Lenzer Jr, and H. Zhan. 2016. The increasing financialization of China's urbanization. Issues \& Studies 52 (04):1640002.

Theurillat, T., N. Vera-Büchel, and O. Crevoisier. 2016. Commentary: From capital landing to urban anchoring: The negotiated city. Urban Studies 53 (7):1509-1518.

Tsui, K. Y. 2011. China's infrastructure investment boom and local debt crisis. Eurasian Geography and Economics 52 (5):686-711. 
Wang, Y. P., L. Shao, A. Murie, and J. Cheng. 2012. The maturation of the neo-liberal housing market in urban China. Housing Studies 27 (3):343-359.

Ward, C., and E. Swyngedouw. 2018. Neoliberalisation from the ground up: Insurgent capital, regional struggle, and the assetisation of land. Antipode.

Ward, C., J. van Loon, and G. Wijburg. 2019. Neoliberal Europeanisation, Variegated Financialisation: common but divergent economic trajectories in the Netherlands, United Kingdom and Germany. Tijdschrift voor Economische en Sociale Geografie. 110(2), 123-137.

Wei, S-J, X. Zhang, and Y. Liu. 2017. Home ownership as status competition: Some theory and evidence, Journal of Development Economics 127(2): 169-86.

Wu, F. 2015a. Commodification and housing market cycles in Chinese cities. International Journal of Housing Policy 15 (1):6-26.

---. 2015b. Planning for growth: urban and regional planning in China. London: Routledge.

- - . 2018. Planning centrality, market instruments: governing Chinese urban transformation under state entrepreneurialism. Urban Studies 55: 1383-1399.

- - . 2020. Land financialization and the financing of urban development in China. Land Use Policy (forthcoming).

Wu, F., Zhang, F.Z., Webster, C. 2013. Informality and the development and demolition of urban villages in the Chinese peri-urban area. Urban Studies 50: 1919-1934.

Yang, D. T. 2012. Aggregate savings and external imbalances in China. Journal of Economic Perspectives 26(4): 125-46. 
Yang, D. T., Zhang, J., \& Zhou, S. 2012. Why are saving rates so high in China? In J. P. H. Fan \& R. Morck (Eds.), Capitalizing China (pp. 249-278). Chicago: University of Chicago Press.

Yang, Z., Y. Fan, and C. H-Y. Cheung. 2017. Housing assets to the elderly in urban China: To fund or to hedge? Housing Studies 32(5): 638-58.

Yuen, B. 2002. Singapore. In Housing policy systems in South and East Asia (pp 38-59), edited by M. R. Agus, J. Doling, D-S Lee,. Berlin: Springer.

Zhang, Y., 2018. Grabbing land for equitable development? Reengineering land dispossession through securitising land development rights in Chongqing. Antipode $50,1120-1140$.

Zhao, S. X., J. L. Ching, Y. He, and N. Y. M. Chan. 2017. Playing games and leveraging on land: Unfolding the Beijing Olympics and China's mega-event urbanization model. Journal of Contemporary China 26 (105):465-487. 
FULONG Wu is Bartlett Professor of Planning at University College London, 14 Upper Woburn Place, London, WC1H 0NN. E-mail: fulong.wu@ucl.ac.uk. His research interests include urban development in China and its social and sustainable challenges.

JIE CHEN is Professor at Shanghai Jiao Tong University, Huashan Road 1954, Shanghai 200030, China. E-Mail: chenjie100@sjtu.edu.cn. His research interests focus on China's housing development.

FENGHUA PAN is an Associate Professor at Beijing Normal University, No. 19 Xin Jie Kou Wai Street, Haidian District, Beijing. China, 100875, and has been Research Associate of this ESRC project at University College London. E-mail: panfenghua@bnu.edu.cn. His research interests are Chinese financial geography.

NICK GALLENT is Professor of Housing and Planning at University College London. 14 Upper Woburn Place, London, WC1H 0NN. E-mail: n.gallent@ucl.ac.uk. His research focuses on UK planning policy as it pertains to housing delivery and as it affects rural communities.

FANGZHU ZHANG is Associate Professor at University College London, 14 Upper Woburn Place, London, WC1H 0NN. E-mail: fangzhu.zhang@ucl.ac.uk. Her research interests include China's innovation and sustainable development. 